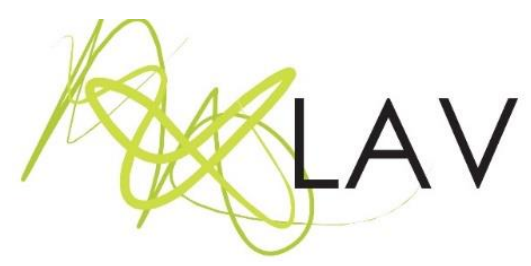

\title{
A fotografia performática de Claude Cahun
}

\author{
The performative photography by Claude Cahun
}

Ana Paula Sabiái

Universidade do Estado de Santa Catarina

\section{Resumo}

Este ensaio busca contextualizar a obra literária e artística de Claude Cahun que, assim como no início do século XX, ainda hoje continua inclassificável. Seu trabalho situa-se, aparentemente, em algum lugar entre lugares: denominações, linguagens, gêneros, realidade e autoficção, entre o inédito e o mítico. Suas experiências radicais na arte, literatura e na política fizeram-na, simultaneamente, tanto vanguardista quanto outsider. Propôs a fluidez entre os papéis identitários pois não lhe interessava repetir-se para os outros, muito menos para si propria. Rompeu com as categorias binárias e dualismos impostos pela normativa social e em concordância com a efervescência instituída ao pensamento moderno, do marxismo à psicanálise, da interpretação da subjetividade e as inúmeras indagações filosóficas sobre a presença do sujeito no mundo, obviamente abordadas na arte, Claude colocou a busca pela 'Verdade' sob suspeita.

Palavras-chave: Claude Cahun, fotografia, identidade, performance, persona.

\begin{abstract}
This essay aims to contextualize Claude Cahun's literary and artistic works which remain to this day, as well as in the early 20th century, unclassifiable. Her work lies, apparently, in a place in-between places: denominations, languages, genres, reality and autofiction, between the unprecedented and the mythic. Cahun's radical experiences in the Arts, Literature and Politics made her, simultaneously, a vanguardist and an outsider. She proposed fluidity amongst identity roles, because she had no interest in repeating herself to others, even less to herself. She broke off with binary categories and dualisms imposed by social norms and in agreement with the effervescence instituted to modern thinking, from Marxism to psychoanalysis, the interpretation of subjectivity and the numerous philosophic inquiries regarding the subject's presence in the world, obviously approached in Art, Claude definitely put the quest for 'the Truth' under suspicion.
\end{abstract}

Keywords: Claude Cahun, photography, identity, performance, persona. 


\section{Persona}

Em meio às dezenas de imagens fotográficas que nos são ofertadas diariamente, sejam para acariciar ou ofender nossa sensibilidade, uma destas em razão da primeira, tornouse indelével para mim quando em ocasião de uma busca esquecida no Google. Trata-se de um retrato em preto e branco de uma pessoa em pé trajando uma volumosa capa preta, de tecido sedoso, fechada na frente, na qual estão presas como broches, dez máscaras carnavalescas e/ou teatrais que assemelham-se ao pulcinella ${ }^{1}$ : encobrem apenas a área do rosto ao redor dos olhos e sobre o nariz.

Sob a capa, percebe-se um barrado de outra peça de roupa preta similar a uma saia na altura dos joelhos; suas pernas ligeiramente paralelas são cobertas pela fina meia branca e nos pés, nobres sapatos negros de salto grosso no estilo Luís XV. A pessoa de sexo indefinido coloca-se em postura impávida; seu rosto está, propositalmente, oculto ao espectador sob outra inquietante máscara, essa com feições femininas. Seus cabelos orientais negros e lisos brilham sedosos como o tecido da capa e por trás dessa misteriosa figura pendem volumosas cortinas estampadas (Figura 01).

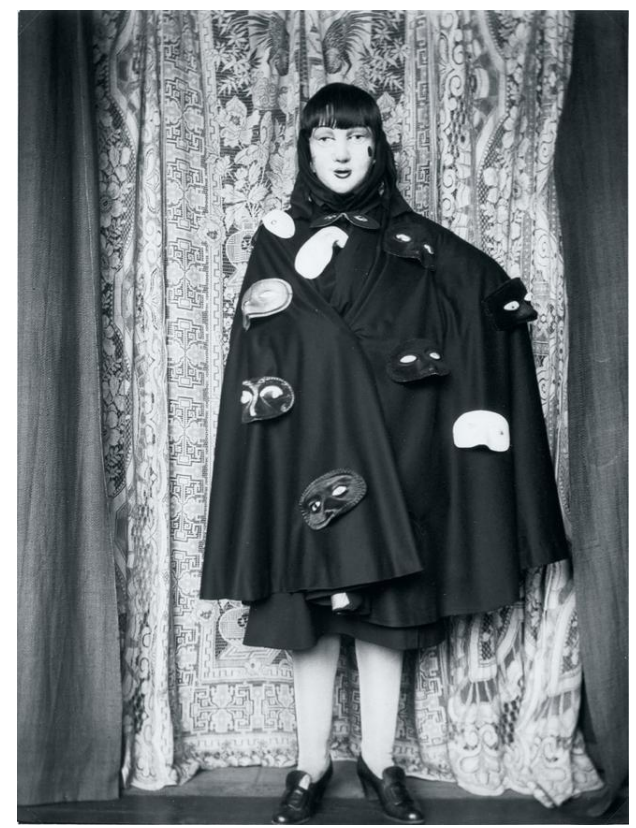

Figura 01. Claude Cahun, Untitled, c.1928. Photography, Gelatin silver print.

Fonte: Courtesy and copyright Jersey Heritage.

Como defende Fernando Braune (2000) a respeito do aspecto surrealista presente em qualquer fotografia e que, por tal razão, nos comove e desafia a perscrutar o que está para

\footnotetext{
1 Personagem burlesca napolitana da Commedia dell'Arte.

Revista Digital do LAV - Santa Maria - vol. 12, n. 1, p. 54 - 81 - jan./abr. 2019 ISSN 1983 - 7348 http://dx.doi.org/10.5902/1983734832200
} 
além do visível plasmado na imagem mesma; essa indefinível criatura instiga: nem masculina nem feminina, fantasmagórica mas resoluta, convidativa e hermética. Ela, a entidade, ali está a nos observar e aguardar como um/a anfitriã/o paciente. Qual das máscaras escolher? A oferta é variada. Sob a máscara quem está? Sob a máscara, quem sou, quem somos? Aceito o convite desta presença velada e, assombrada, adentro às cortinas...

A máscara é um artefato ancestral que perpassa toda a historia da humanidade nas mais diversas culturas. Remete ao sagrado e profano, ao longínquo e contemporâneo, transita entre o simular e desvelar, o exagero e a sutileza, a entrega e o narcisismo, media entre o coletivo e individual, entre o social e subjetivo, entre o espírito e a matéria, entre o racional e o instinto.

No antigo teatro greco-romano, os atores assumiam a face mascarada, trágica ou cômica, de seu personagem. Interpretavam um estereótipo pré-determinado - seja ele o herói, a esposa, o comerciante, o sábio, entre outros - nas feições exageradas e enrijecidas daquelas máscaras. Há de se recordar que eram os homens, sob o disfarce da persona, é quem interpretavam as mulheres já que estas, não consideradas cidadãs, não tinham direito político na polis.

Jung reelabora o significado da máscara utilizada no antigo teatro grego em sua psicanálise analítica. ${ }^{2}$ Segundo ele, todo sujeito torna-se um ser social assumindo personas diferentes em contextos diversos, pois a manifestação dessa flexibilidade psíquica, quando saudável, está a serviço tanto da individuação quanto do impulso da saída de auto-centramento em direção ao coletivo (JUNG, 2008).

A persona é, neste sentido, um arquétipo ${ }^{3}$, uma máscara simbólica que escolhemos cotidianamente para interpretar a nós mesmos em variadas situações sociais: em casa, no trabalho, nos relacionamentos amorosos, em família, no lazer, enfim, nas mais dispares situações do palco da vida.

\footnotetext{
2 Carl Gustav Jung (Suíça, 1875-1961), fundador da psicologia analítica, propôs e desenvolveu conceitos como personalidade extrovertida e introvertida, arquétipo e inconsciente coletivo.

3 Jung afirmava que a mente humana, assim como qualquer ser no processo de evolução da espécie, mantinha uma experiência primordial armazenada progressivamente nas sucessivas gerações que se configuram como inconsciente coletivo. São imagens primordiais, independentes de determinada cultura, que conecta a todos os seres humanos e se repetem em qualquer época ou lugar do mundo, como formas primitivas inatas e herança do espirito humano (JUNG, 2008).
} 
Pelo aspecto negativo, ainda a partir da psicanálise analítica de Jung, pode acontecer por variados instâncias da psique ${ }^{4}$, que uma determinada persona seja inteiramente assumida pelo ego (centro da consciência) de determinado indivíduo, a ponto deste negar sua essência primordial. $O$ indivíduo enrijece-se a apenas uma personagem para o bem ou para o mal.

Essa problemática está brilhantemente colocada no filme Persona (1966) de Ingmar Bergman. A trama se constrói a partir da atriz Elizabet Vogler (interpretada por Liv Ullman) que durante sua apresentação da peça Electra de Sófocles, repentinamente para de falar. No hospital em que faz seus exames Ihe é destinada a enfermeira Alma (Bibi Andersen), responsável por cuidados de sua saúde em uma casa próxima ao mar. Como forma de aproximação, a enfermeira busca quebrar o silêncio absoluto de sua paciente narrando à ela, continuamente, suas vivências e segredos pessoais. Aqui residem os enigmas e o apogeu, a belíssima fotografia do filme e a magistral direção do enredo, que modula tanto os contrastes quanto as similitudes entre as personagens - a atriz e a enfermeira - a ponto de confundi-las e nos confundir, sobre quem é quem.

De modo semelhante, pode-se relacionar persona e heterônimo, já que o segundo possibilita ao autor a constituição e apropriação de outras personalidades como se fossem pessoas de carne, osso, biografia e estilos literários próprios.

Heterônimos e personas são possibilidades do ser e não ser. Como não se surpreender com a distinta prosa e biografia ficcional de Alberto Caeiro, Ricardo Reis e Álvaro de Campos $^{5}$, os heterônimos mais populares de Fernando Pessoa?

E como interpretar o pseudônimo? Este também não trata-se, de certo modo, de uma máscara social? Empolgante concebê-lo não em falsidade ou embuste do próprio nome, mas na inventividade deste, na criação, no descobrimento, na concepção, no engenho, na ideia, na fantasia, na ficção, na ilusão, na fábula. De mesmo modo, também, na assunção dos heterônimos e das personagens mascaradas.

\footnotetext{
${ }^{4}$ Em termos genéricos, Jung conceitua que a psique é somente o inconsciente. O ego emerge do inconsciente e reúne inúmeras experiências e memórias, desenvolvendo assim a divisão entre o inconsciente e o consciente. (JUNG, 2008).

${ }^{5}$ Alberto Caeiro, nasceu em 1889, em Lisboa. Órfão de pai e mãe, não exerceu qualquer profissão e estudou apenas até a $4^{a}$ série. Vida pobre e frágil no Ribatejo. Escreveu O Guardador de Rebanhos, O Pastor Amoroso e Os Poemas Inconjuntos, antes de morrer de tuberculose, em 1915, aos vinte e seis anos de idade. Ricardo Reis, recebeu uma forte educação clássica num colégio de jesuítas e formou-se em Medicina. Viveu no Brasil desde 1919, É um latinista por educação, e um semi-helenista por educação propria, além de que gostava de andar de cavalo. Alvaro de Campos, recebeu educação de liceu, estudou engenharia mecânica e naval na Inglaterra, viajou ao Oriente, trabalhou em Londres em 1922. Desempregado, teria voltado para Lisboa em 1926, mergulhando então num pessimismo decadentista.
}

Revista Digital do LAV - Santa Maria - vol. 12, n. 1, p. 54 - 81 - jan./abr. 2019 ISSN 1983 - 7348 http://dx.doi.org/10.5902/1983734832200 
A figura enigmática da fotografia que nos introduziu neste devaneio reaparece agora em outro retrato, totalmente despida de toda vestimenta, exceto por outra máscara. Está sentada frontalmente, os braços dobrados sobre o peito, os cotovelos se tocam, as mãos apoiadas sobre os ombros. As pernas fechadas e dobradas lateralmente, ambos os joelhos em primeiro plano estão iluminados à semelhança do joelho barroco de Narciso, de Caravaggio. Seu corpo é magro, ombros estreitos, rosto ovalado, cabelos curtíssimos e loiros. Seu sexo, apesar da nudez, ainda indefinido. A figura toda se expõe mas ainda nos está velada. O contraste da luz solar sobre o corpo se contrapõem a uma perturbadora sombra que delimita um vão retangular alojado acima da cabeça da retratada (Figura 02).

A autoria e as personas nestas imagens é de Claude Cahun, pseudônimo adotado em 1917 por Lucy Renée Mathilde Schwob.

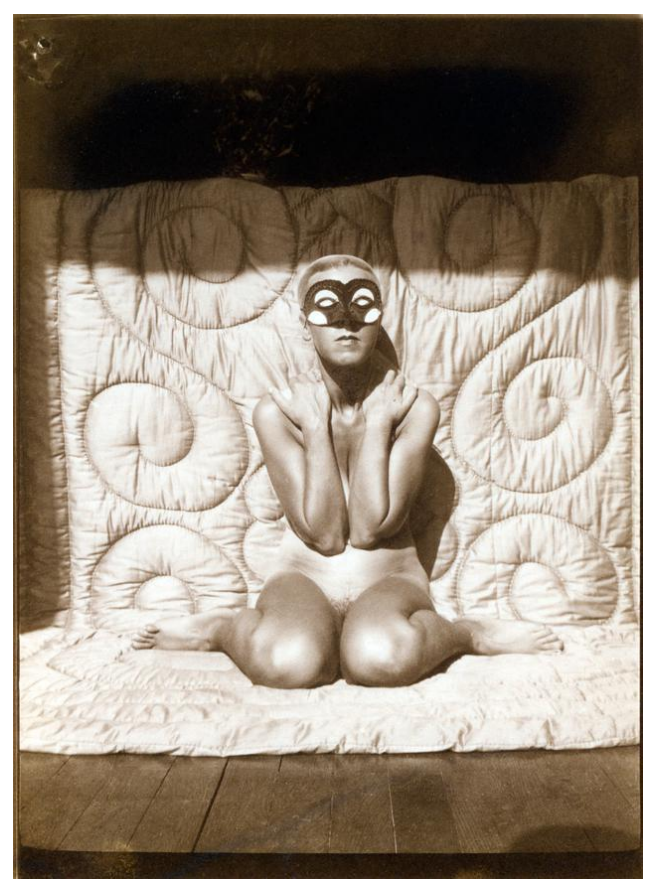

Figura 02. Claude Cahun, Self-portrait Photography, Gelatin silver print, c.1928. Fonte: (c) Jersey Heritage.

\section{Duplo/a}

Claude Cahun, figura notável que por muito tempo esteve quase esquecida e deixada de fora dos 'holofotes' da arte, reapareceu há poucas décadas como grande referência e interesse aos atuais estudos e problematizações das identidades e políticas queer. $\mathrm{O}$ caráter descritivo e biográfico do presente texto propõe uma investigação específica em 
torno de uma artista que transitou em liberdade entre os rótulos de gênero, linguagens e nas construções imagéticas de si.

Nascida em 1894 (Nantes, França) no seio de uma renomada família literata6, Claude Cahun inicia seus primeiros escritos e fotografias entre 1910 e 1915, colaborando em populares revistas e jornais franceses. No início da década de 1920 transfere-se à Paris estabelecendo amizade com escritores, artistas e atores em ocasião na qual publica seus primeiros poemas e ensaios.

Claude é uma figura emblemática. Praticamente esquecida após sua morte em 1954 foi redescoberta, por acaso, nos final dos anos 1970 pelo filósofo e poeta François Leperlier que, curioso de sua obra, apelou em um jornal para qualquer pessoa que a tivesse conhecido entrasse em contato com ele. Leperlier tornara-se, a partir daí, a figura central no resgate do trabalho e memória de Cahun: escreveu livros sobre a artista, organizou exposições de seu trabalho fotográfico e, concomitantemente à onda cultural andrógina dos anos 1980 e da emergência queer dos 1990, contribuíram para popularizar a obra dela.

Claude é ambígua. Apresenta-se através de autorretratos, encena a si mesma, reinventase artisticamente, desafia-se socialmente, provoca-se sexualmente, questiona os pressupostos identitários. Propõe a si própria, através de sua arte-vida, inscrever-se como sujeito-plural, andrógina, desviante das normas e classificações, "Neutro é o único gênero que me convém", Cahun (2017, p. 118) afirmava.

Assumiu-se lésbica desde muito jovem e sua companheira e colaboradora profissional por quase cinco décadas foi Marcel Moore, pseudônimo de Suzanne Malherbe. Considerava-se, antes de tudo, escritora. Contudo, diante da variedade de autorretratos e inventividade nas personalidades construídas diante das lentes percebe-se que a fotografia também constituiu-se como experimentação constante, como personas criativas sob a máscara de Lucy, máscara de Claude, máscara da amante, máscara da escritora, máscara da artista, máscara da militante, máscaras do que se queira e quem deseja ser.

Cahun estivera além de seu tempo. A problemática da identidade como rigidez e repetição de si mesma era criticamente exercitada por ela assim como, também, as questões de autoria, de gênero, da produção da 'verdade'. Claude e sua namorada Marcel Moore, que também era artista e designer gráfica, trabalhavam juntas na elaboração dos retratos de

\footnotetext{
6 "Filha de Maurice Schwob, diretor e proprietário do jornal Le Phare de la Loire [...] Sobrinha do escritor simbolista Marcel Schwob e sobrinha-neta de Léon Cahun, orientalista e romancista" (CAHUN, 2017, p. 135).
}

Revista Digital do LAV - Santa Maria - vol. 12, n. 1, p. 54 - 81 - jan./abr. 2019 ISSN 1983 - 7348 http://dx.doi.org/10.5902/1983734832200 
Cahun. Em muitos destes, especula-se que enquanto ela posava, Moore a dirigia e a fotografava.

Sua arte-vida insere-se em um contexto histórico-social entre guerras, no seio de uma sociedade que amargava um desalento das aspirações humanistas prometidas pelos homens da razão e da ciência. O artista moderno, diante deste trágico cenário, repudia a sociedade burguesa e tudo o que esta representa: seus costumes, a sua moral, seu modo de vida. Perturbados por certo mal estar na arte iniciam, a partir do final do século XIX, um processo psicossocial de compreender-se também enquanto um personagem de si e do mundo (FRAYZE-PEREIRA, 2005).

\section{O "eu" fragmentado da Modernidade}

Na primeira metade do século XX se estabelece uma espécie de vínculo entre arte e angústia, entre a forma e o vazio que a interpela, já que a sociedade moderna agora se compreendia desvinculada de poderes divinos, antes 'manifestados' através do mistério da criação. O lugar dessa ausência de mistério deu lugar à condenação moral e estética. 0 delírio e improvisação do ato criativo de outrora era julgado como algo negativo, pressuposto de loucura e preguiça. Nessa redefinição contem noções abusivas da moral burguesa para o campo da estética (FRAYZE-PEREIRA, 2005).

A modernidade compreendida entre final do século XIX e todo o XX marca mudanças significativas no pensamento ocidental no qual emergências de ordens variadas, do surgimento de novas ciências humanas às sociais, das relações de trabalho à urbanização, da produção ao consumo, da política à arte, etc., trazem ao Homem moderno a necessidade de uma crítica reflexiva sobre si e o mundo, buscando compreender essa teia de relações sociais como uma construção histórica, social e política.

Segundo Frayze-Pereira (2005), entre o final do século XIX e primeiros anos do século XX, uma genealogia da história da loucura começa ser fonte de pesquisa nas ciências e nas artes. Em paralelo àquelas transformações sociais, a poética artística europeia do início do século XX incorpora uma revalorização da arte arcaica, do exotismo das culturas não ocidentais, da arte negra, das garatujas infantis, da estranheza dos grafismos dos psiquiatrizados.

Muitos artistas de vanguarda assumem uma estética que seria considerada a dos marginais, loucos, excluídos socialmente, a arte dos não ocidentais, dos negros e das 
mulheres, ou seja, aquela arte que não comungava dos cânones de uma cultura por eles julgada comprometida.

Essa dissociação com os valores da sociedade moderna, industrial e excludente, faz do artista moderno um expatriado, um duplo de si, um estrangeiro em sua própria terra, um cavaleiro errante, um romântico que buscava esperança através da negação da realidade embrutecida, da admissão do delírio, da fuga política e social.

Nesse contexto, o dadaísmo e o surrealismo, movimentos artísticos da vanguarda européia, também influenciados pelas ideias do materialismo histórico de Marx, da filosofia 'do martelo' de Nietzsche e da psicanálise de Freud, tornam-se análogos à esse cenário.

Claude interessa-se pela quebra de padrões, pela duplicidade, pela experimentação da ideia de identidade, busca retratar-se retratando um 'eu' que é outro e vice-versa. Ela age e pratica as simultaneidades identitárias em sua própria trajetória. Dedica-se ao teatro e atua com dedicação, estuda letras e filosofia na Sorbonne, pesquisa doutrinas orientais e artes esotéricas, traduz estudos de psicologia social, colabora com revistas de assuntos variados (como moda e homossexualidade), participa de pesquisas, publica manifestos políticos. Toda a diversidade de seus interesses era continuamente praticada em sua literatura e seus retratos fotográficos. As duas fotografias a seguir, realizadas em 1928 e 1929, nos apresentam alguns dos seus desafios (Figuras 03 e 04).

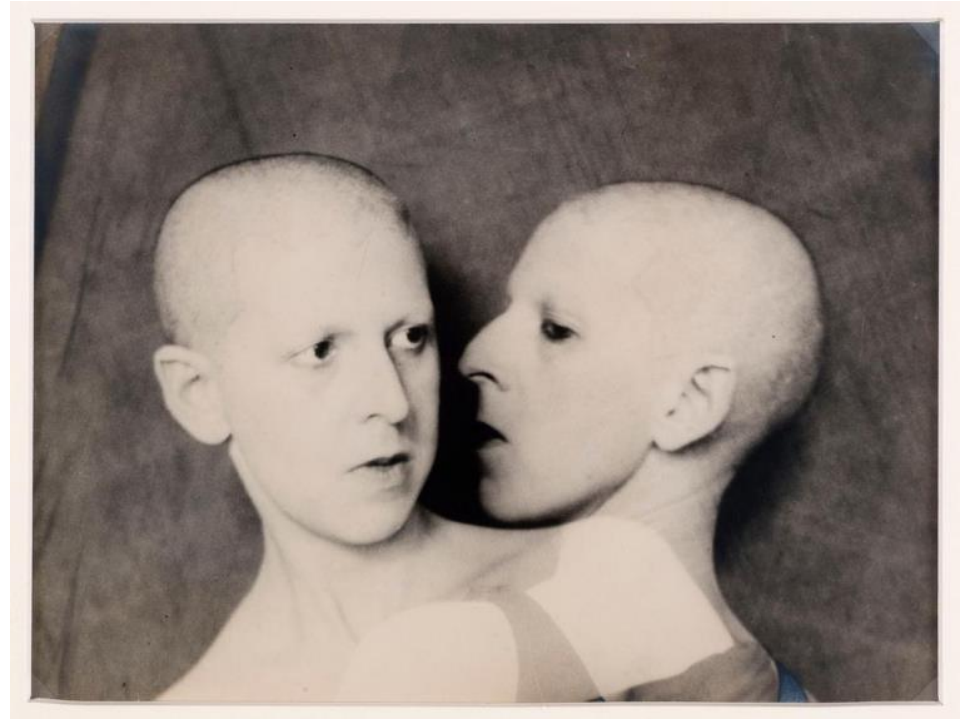

Figura 03. Claude Cahun, What do you want from me? Photography, Gelatin silver print, 1928 - Fonte: Trivium Art History 


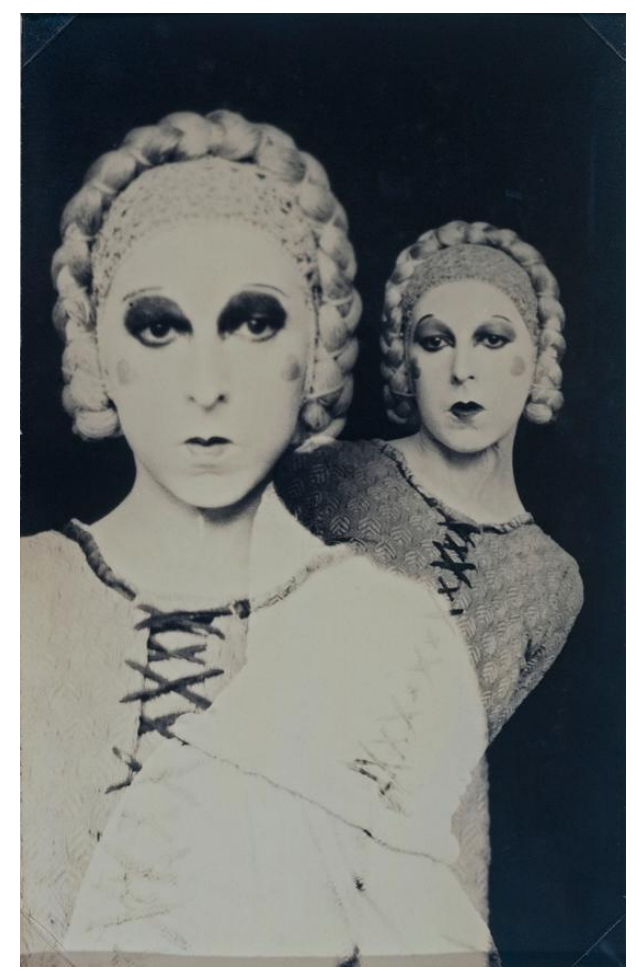

Figura 04. Claude Cahun, Autoportrait, 1929.

Photography Gelatin silver print, dimensão $14 \times 9 \mathrm{~cm}$.

Fonte: Musée d'Art Moderne de la Ville de Paris/Parisienne de Photographie.

Trata-se de sobreposições fotográficas, ou seja, diferentes fotografias que amalgamadas na pós produção torna-se uma, conferindo à mesma imagem a noção de simultaneidade. O efeito dessa técnica, muito utilizada naquele período pelos artistas dadaístas e surrealistas, confere um estranhamento, inquietação, anti-naturalidade, contradição, ritmo, pois nosso olhar desloca-se entre as várias imagens, buscando estabelecer relações entre elas.

O título 'What do you want from me?' (Figura 03) é bastante sugestivo, pois Cahun não costumava intitular seus retratos. Observamos o retrato duplicado de uma mesma pessoa que se tornam duas. Talvez possam ser gêmeas, amantes, adversárias, simbolizem corpo e alma ou a mesma pessoa em diferentes situações. Conforma-se como representação da ideia dos muitos eus que nos constituem e as inerentes afeições: o oculto, o irracional, o que se gostaria de ser, o que nos aprisiona, a virtualidade do vir a ser ou do que poderia ter sido a partir de escolhas outras. As leituras dessa imagem, como de qualquer outra, são inúmeras. 
Nessa fotografia, Claude insere-se no limiar entre gêneros com cabelos raspados, ombros nus e fundo neutro. Não se pode afirmar certeza de masculinidade ou feminilidade, mas é fatalmente um retrato de um ser andrógino.

De modo similar, aparece a seguir (Figura 04) uma persona dual e fantasmagórica, ambas a mirar-se entre si como que refletidas por um espelho. A lente da camera transforma-se aqui e, consequentemente o nosso olhar de espectador, no espelho que as reflete. Elas estão a se olhar através do nosso olhar. Como em um jogo de cartas, são personagens coringas, indecifráveis, inesperados, que ajudam ou atrapalham a jogada. Isso dependerá do jogo que se joga.

Na modernidade o sujeito passa a ser compreendido a partir de uma construção histórica, sendo constituído de 'camadas arqueológicas' estratificadas: sujeitos humanistas (descentrado do Divino), sujeitos da razão, sujeitos de direito (em relação ao Estado com suas leis, direitos e deveres), sujeito indivíduo (sob o estatuto da individualidade, com existência e corpo individualizado, livre e autônomo), sujeito trabalhador (relação com o Capital e consumo) e sujeito psicológico (em relação ao que dá sentido à singularidade). Inegavelmente, o sujeito através dos tempos, estando dentro ou fora dos limites dos seus enunciados exerce produção e significação de relações de poder.

\section{Identidade e resistências}

A estrutura da sociedade moderna, e suas organizações disciplinantes, foi edificada entre os séculos XVII e XVIII. Se desde o século XVI, a forma política de poder territorial do Estado ignorava indivíduos em nome do interesse na totalidade, na classe ou grupo de cidadãos, a partir da modernidade esse fato é alterado com a necessidade de controle ao indivíduo.

O Estado resgata uma forma política originária das instituições cristãs, o poder pastoral, no qual seu poder é tanto individualizante como totalizador. Não interessava ao Estado uma massa de indivíduos anônimos que pudessem fugir ao controle, era preciso marcálos cada um com a sua identidade (PRADO FILHO, 2010).

O pastorado garante a condução das ovelhas e assegura sua salvação de acordo com suas condutas. Esse poder pastoral aplicado pelo Estado vem revestido de sedução e do apelo educativo, pedagógico e subjetivante que o torna muito mais difícil de resistir, pois assegura aos indivíduos saúde, bem-estar, segurança, proteção contra acidentes, garantia 
de direitos e possui uma tecnologia de poder, tanto globalizadora e quantitativa (população), quanto analítico (indivíduo).

Nesse contexto, Foucault (1995) traz a analogia entre o controle das condutas que se dá através da regulação das identidades, no qual o poder pastoral governa as almas e o poder do Estado governa os vivos, ou seja, suas condutas. De acordo com o filósofo, a regulação da identidade perpassa constantemente pela sexualidade sendo um dos mecanismos de maior controle e normativa social fixados nos corpos dos indivíduos.

$\mathrm{Na}$ cultura ocidental existe, segundo Foucault, diferentes formas pelos quais os seres humanos tornam-se sujeitos a partir de diversos modos de objetivação: pelo simples fato de estar vivo, sob a constatação natural e biológica; através da produtividade, ou seja, o sujeito que trabalha, produz riqueza e movimenta a economia; através da investigação que opera pela ciência; através das chamadas 'práticas divisórias' na qual o sujeito sofre classificações como, por exemplo, louco e são, doente e sadio, etc; e, através da sexualidade.

A teoria política como ciência do possível num campo de enfrentamentos é uma produção moderna que propõe modos de resistência contra as diferentes formas de poder. Estas, por sua vez, devem ser pensadas a partir de necessidades conceituais específicas para cada tipo de realidade.

Foucault desloca as relações de poder Estado-sociedade, não compreendendo a política como relação macro, mas sim considerando-a como fenômeno social e/ou micro-social: as relações de poder como tecido político. Neste contexto, o poder não é algo que se detenha, se aproprie ou seja concentrado, mas é exercido através da relação entre indivíduos ou entre grupos, caracterizando uma horizontalidade do poder. Entende-se o poder como resistência e enfrentamento nas relações móveis e assimétricas.

Considerando sua influente reputação literária familiar, Claude Cahun usufruía também de conforto material que a liberava da obrigatoriedade de um trabalho condicionado para seu sustento. Pode se dar ao prazer de produzir suas fotografias, performances e escrita experimental não, necessariamente, destinadas ao consumo e venda à determinado público mas, prioritariamente, para si mesma e seus entes amados. No entanto, ao infiltrar em sua arte-vida experiências e ações de natureza ambivalente, subversiva, crítica, sexual, fora dos padrões morais de sua época e contexto, Claude afirmou a si e sua arte na arena política. 


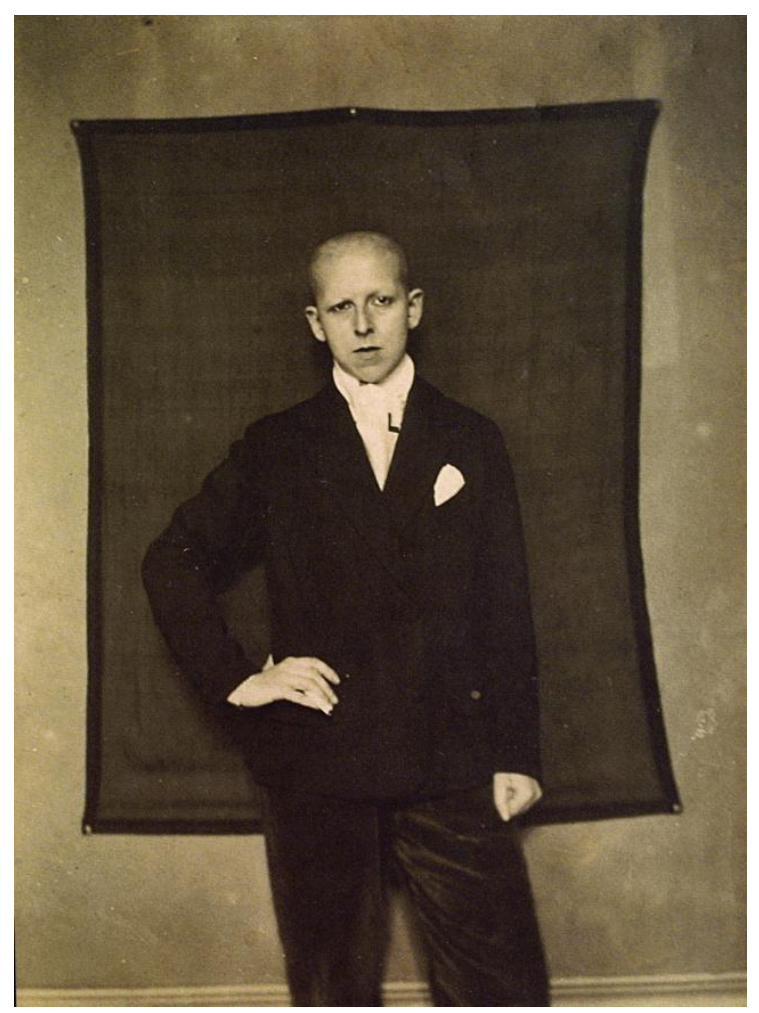

Figura 05. Claude Cahun, Untitled,1921-22.

Photography, Gelatin silver print, Dimensions 23.7 × $15 \mathrm{~cm}$

Fonte: MOMA/collection.

No autorretrato de 1920 ela aparece em pé em postura frontal, cabelos raspados, sem maquiagem nem adereços, trajada elegantemente em um terno masculino de veludo preto, um foulard no pescoço e um lenço no bolso do paletó. Um expressão afirmativa em seu olhar desafia o olhar do espectador. As posições das mãos complementam a ambiguidade: enquanto a direita repousa delicadamente na cintura, a mão esquerda está fechada em punho, sugerindo a ideia de enfrentamento (Figura 05).

Um similar confrontamento aparece em uma fotografia da jovem Frida Kahlo, em 1924. Artista também reconhecida por suas construções identitárias, Frida burla os rígidos padrões burgueses ao inserir-se no retrato de família trajada, penteada e em pose como se fosse um rapaz (Figura 06). 


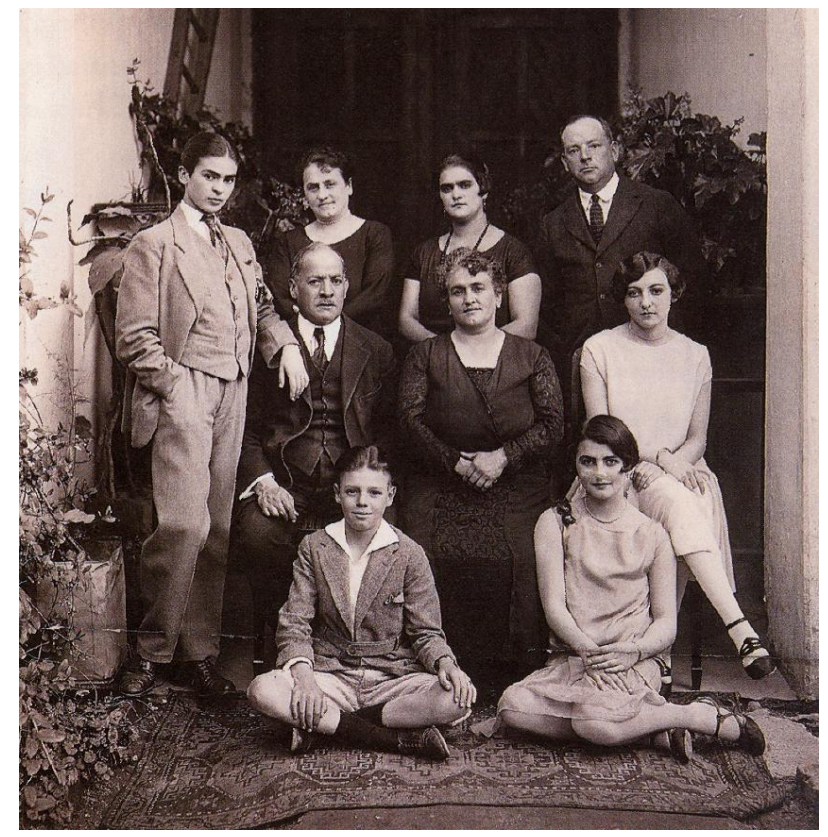

Figura 06. Guilhermo Kahlo, 16 year old Frida Kahlo wearing her father's suit. Family portrait, 1923.

Fonte: Image provided by Frida's Blue House.

Outro artista que provocou os rótulos de gênero neste período, foi o mestre da subversão Marcel Duchamp através de seu alter ego feminino Rrose Sélavy. Em retrato feito pelo amigo Man Ray, Duchamp transfigura-se nessa mulher de rebuscada postura burguesa, chapéu coco, estola de pele e expressão maquiada e serena. As mãos meticulosas em pose delicadíssima e uma dedicatória, escrita com letra cursiva na lateral posterior direita da imagem, endossa uma aura de credibilidade à 'respeitosa' madame (Figura 07). 


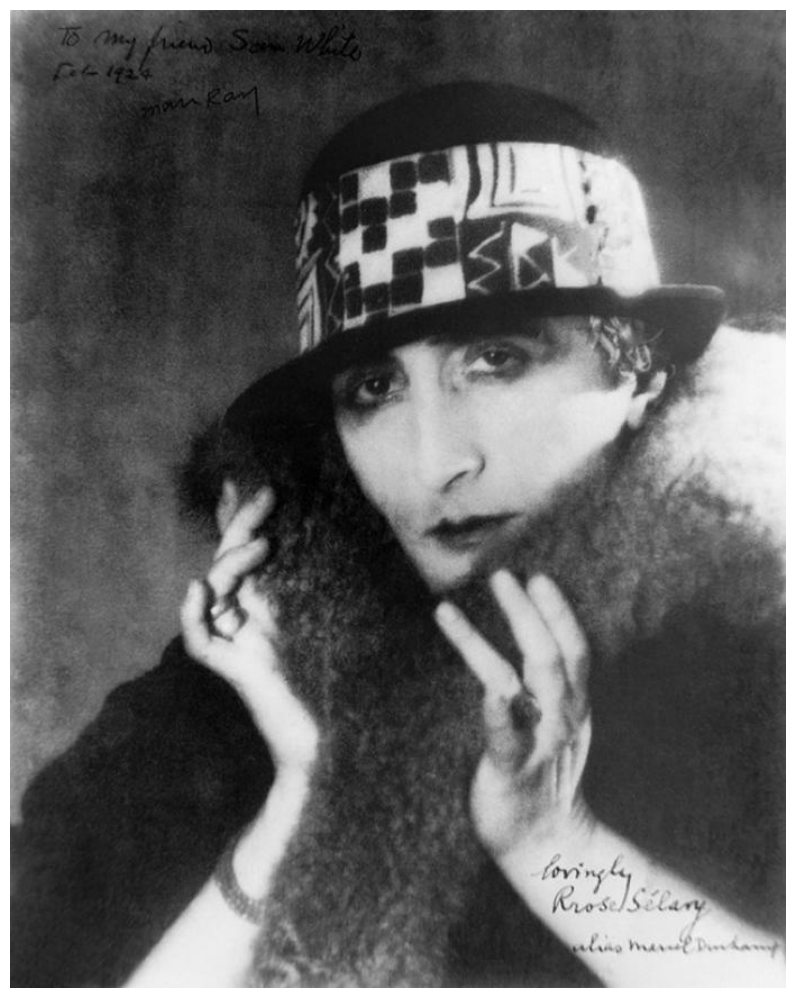

Figura 07. Rrose Sélavy Marcel Duchamp and Man Ray (1890-1976).

Gelatin silver print, hand-retouched by Duchamp in black ink and pencil, 1921.

Fonte: Private collection (c) 2009 Man Ray Trust/Artists Rights Society(ARS), NY/ADAGP, Paris.

Rrose era uma extensão da tradição da androginia e da inclinação de gênero nos retratos; afinal, Duchamp refez a Mona Lisa como homem quando desenhou um bigode e uma barba em um cartão postal da pintura de Da Vinci. Seu pseudônimo feminino não supunha truques, pois era apenas uma das muitas tentativas de provocar ideias sobre identidade e auto-representação, particularmente em retratos de si mesmo. Outros exemplos incluíram fotos que o encenavam como um criminoso e montagens fotográficas, retratando-o simultaneamente sob cinco pontos de vista diferentes, mas Rrose, em particular, é uma das partes mais enigmáticas da obra do artista. Ao criar um alter-ego feminino e envolto em um certo mistério, Duchamp conseguiu equilibrar a arte da contradição, perturbando e sustentando suas ideias e intenções de uma só vez (HAWKINS, 2015).

A originalidade de Claude, no entanto, é a experimentação de si no propósito da invenção de um ser que não se afirma em determinado rótulo, mas intenta colocar-se 'entre' lugares, 'entre' gêneros, entre ideias, entre modos de vida, entre realidade e ficção. 
Observando este retrato de 1931, o surrealismo aparece marcado: Cahun se coloca entre humano e objeto, entre orgânico e imortal, entre limiares. Um ser monolítico dotado de vida e desespero, almejando lançar-se para fora de sua rigidez rochosa em ansiedade nervosa. Os tendões e os dedos abertos, demarcados pelo contraste de luz e sombra criam tensão entre o espaço celeste e a matéria não lapidada (Figura 08).

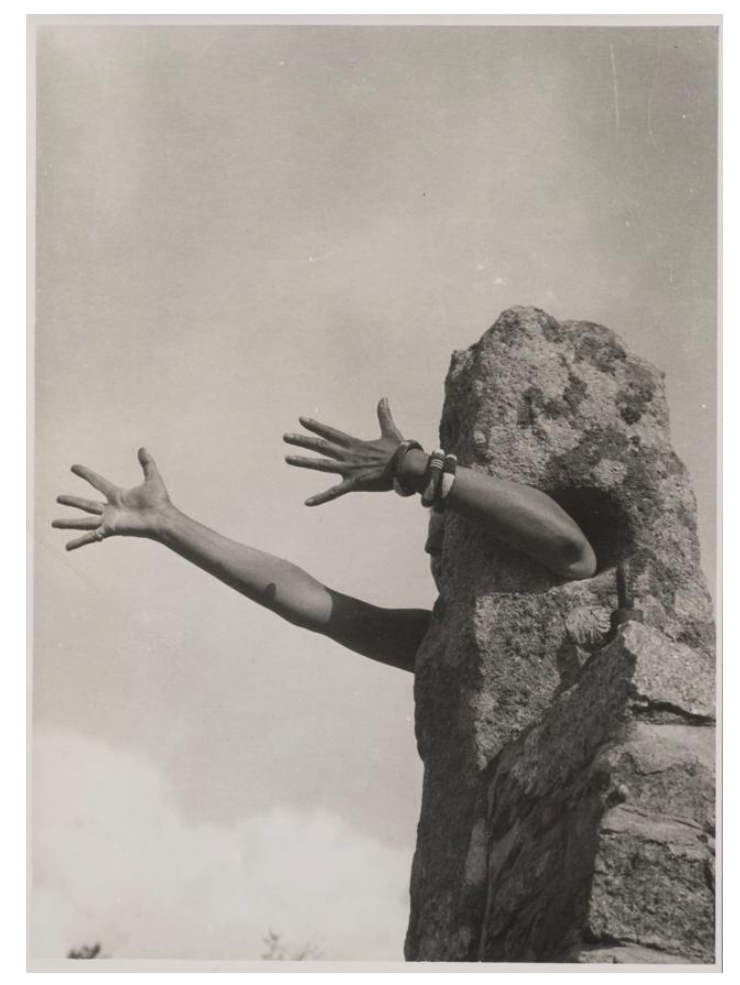

Figura 08. Claude Cahun, I Extend My Arms, c.1931 or 1932.

Photograph, gelatin silver print on paper.

Dimensions: image: 204 × $150 \mathrm{~mm}$.

Fonte:@Tate Images.

Evidente que em nossa sociedade a (re)invenção de si não é incentivada, pelo contrário. Problematizar as normativas, primeiro passo para buscar transformar fatos dos quais não se vai de acordo, é atitude que denota questionamento, auto-crítica e reflexão que induzem ao auto-conhecimento e posicionamento diante das relações assimétricas que trama a tessitura micropolítica.

Ao permitir-se pensar ou fazer diferente o sujeito, como uma 'peça' da engrenagem social, torna-se incômodo ao status quo do poder vigente. Em seu aforismo intitulado 'A sólida reputação', Nietzsche (2012, p. 178) considera: 
Uma reputação sólida costumava ser extremamente útil; e onde quer que a sociedade continue a ser dominada pelo instinto de rebanho, é ainda muito conveniente, para cada indivíduo, fazer com que seu caráter e sua ocupação sejam tidos por imutáveis mesmo que no fundo não o sejam. [...] A sociedade sente, com satisfação, que tem na virtude desse, na ambição daquele, na reflexão e no fervor daquele outro um instrumento confiável e sempre disposto - ela presta o máximo de honras a essa natureza de instrumento, essa fidelidade a si mesmo, essa invariabilidade nas opiniões, nas aspirações e até nos defeitos. Uma tal avaliação, que em toda a parte floresce e floresceu juntamente com a moralidade dos costumes, educa o 'caráter' e difama toda mudança, toda reaprendizagem e transformação de si.

Problematizar questões tangentes à política, ética, social e filosófica de nossos dias não consiste em liberar o indivíduo do Estado e suas instituições, mas desvencilhá-lo do tipo de individualização que a ele se liga. Não é tarefa fácil, mas continua-se na resistência cotidiana aos jogos de poder, na afirmação de si, na busca de relações em pontos de equilíbrio apesar das oscilações, constituições que vão se moldando e remodelando à medida em que se luta.

\section{(auto)Biografia}

A narrativa biográfica como gênero literário tradicional da escrita de histórias de vida dos homens ilustres ${ }^{7}$, heróicos e desbravadores arquiteta de maneira ascendente e sublime suas façanhas sem considerar suas ambiguidades e nem seus vacilos.

Em 1550, o italiano Giorgio Vasari publicou 'Vida dos Artistas', livro que tornou-se o precursor das biografias de artistas e também da 'História da Arte' como a conhecemos no Ocidente $^{8}$. O título original Le vite de' più eccellenti pittori, scultori, e architettori enaltece os mais 'excepcionais, inigualáveis, extraordinários e admiráveis' artistas homens.

Em pleno fortalecimento do Renascimento, como novo paradigma sócio-cultural e econômico, Vasari inaugura uma escrita biográfica que buscava evidenciar, segundo historiadores e não sem uma implicada dose de camaradagem ou desafeto, a maestria daqueles artistas como seres transcendentais, considerando a relação entre a obra artística e a vida pessoal.

\footnotetext{
7 As vidas dos homens ilustres: Sólon ou Vidas Paralelas, obra que exerceu grande influência na literatura ocidental, é uma compilação de várias biografias de homens ilustres da Roma Antiga e da Grécia Antiga, escritas pelo filósofo, historiador e ensaísta grego Plutarco (46 d.C. - 120 d.C.).

${ }^{8}$ Vida dos Artistas, de Giorgio Vasari, teve a sua primeira edição publicada no Brasil em 2011 pela editora Martins, organizado por Luciano Bellosi e Aldo Rossi e tradução de Ivone Benedetti.
} 
De outro modo, as autobiografias oferecem possibilidades literárias de dar-se a apresentar, narrando em primeira pessoa uma experiência vivida pelo próprio indivíduo e, por isso, são mais permeáveis às idiossincrasias, contradições, confissões, sentimentos e pensamentos desviantes. Os diários, cartas, memórias, seja de modo literal ou constituída de elementos ficcionais, encorajam à autobiografia um aspecto de diálogo e não monólogo como acontece nas biografias, entre o autor e o leitor.

Philippe Lejeune, especialista francês em autobiografias e 'escritas da vida cotidiana', criou em 1993 a 'Associação para a Autobiografia e o Patrimônio Autobiográficos' (APA) ${ }^{9}$. Sediada em Ambérieu-en-Bugey, conhecida atualmente como a 'cidade da autobiografia', este arquivo é constituído com mais de dois mil documentos que abrangem os mais conhecidos tipos de literatura pessoal: autobiografia, diário íntimo e correspondência (PERROT, 2017).

A historiadora Michelle Perrot (2017) discorre sobre o fato de que a escrita pessoal, apesar de não ser uma exclusividade feminina, demarcou um caráter intimista que era muito ligado ao contexto privado ou doméstico burguês, destinado à mulher na sociedade ocidental:

De maneira geral, a presença das mulheres nesses arquivos se dá em função do uso que fazem da escrita: é uma escrita privada, e mesmo íntima, ligada à família, praticada à noite, no silêncio do quarto, para responder às cartas recebidas, manter um diário e, mais excepcionalmente, contar sua vida (PERROT, 2017, p. 28).

Apesar disso, até o início do século XX, período em que as mulheres iniciam seu ingresso na esfera pública, era extremamente raro encontrar autobiografias de mulheres. Segundo Perrot, até final do século XIX, o olhar-se para si e para sua trajetória de vida, fazer o balanço da existência e uma escrita desta, era tarefa destinada às pessoas públicas. Se existisse, por raridade, a narrativa de vida das mulheres, geralmente era sob a forma de 'memórias' que evocavam e destacavam os homens que conheceram ou conviveram.

A historiadora brasileira Margareth Rago (2013), através de uma perspectiva feminista, defende em seu trabalho a prática da escrita de si, a partir da leitura foucaultiana, no intento da construção de uma subjetividade que está em constante rearranjo e aberta ao processo inerente do devir, considerando a multiplicidade das redes de relações na qual insere-se o sujeito.

\footnotetext{
${ }^{9}$ Association pour L'Autobiographie et le Patrimoine Autobiographiques.
}

Revista Digital do LAV - Santa Maria - vol. 12, n. 1, p. 54 - 81 - jan./abr. 2019 ISSN 1983 - 7348 http://dx.doi.org/10.5902/1983734832200 
Nesse sentido, a autobiografia deixa de ser uma escrita estritamente individual para abrirse também ao coletivo e às tramas micropolíticas, considerando que a linguagem e os discursos são meios pelos quais se organizam tanto a dominação cultural quanto a resistência.

Em 1930 Claude Cahun publica sua autobiografia intitulada Aveux non avenus ${ }^{10}$. Como era próprio de seu feitio e contexto artístico, trata-se de uma subversão da tradicional autobiografia a partir de uma narrativa anti-realista - híbrida entre realidade e ficção, entre individual e coletiva - com forte apelo surrealista, ilustrada de fotomontagens e aforismos criados por Cahun, na qual forjava sua crítica ao conservadorismo cultural dominante na França após a Primeira Grande Guerra.

Nesse collage fotográfico aparecem fotomontagens, muitos retratos sobrepostos sendo a maioria da própria Claude. Corpos sem cabeça e vice-versa, pássaros, armas, costelas humanas similares às imagens de raio- $X$, um retrato duplicado de um homem sugerindo $o$ hibridismo entre gêneros e corpos fragmentados (Figura 09).

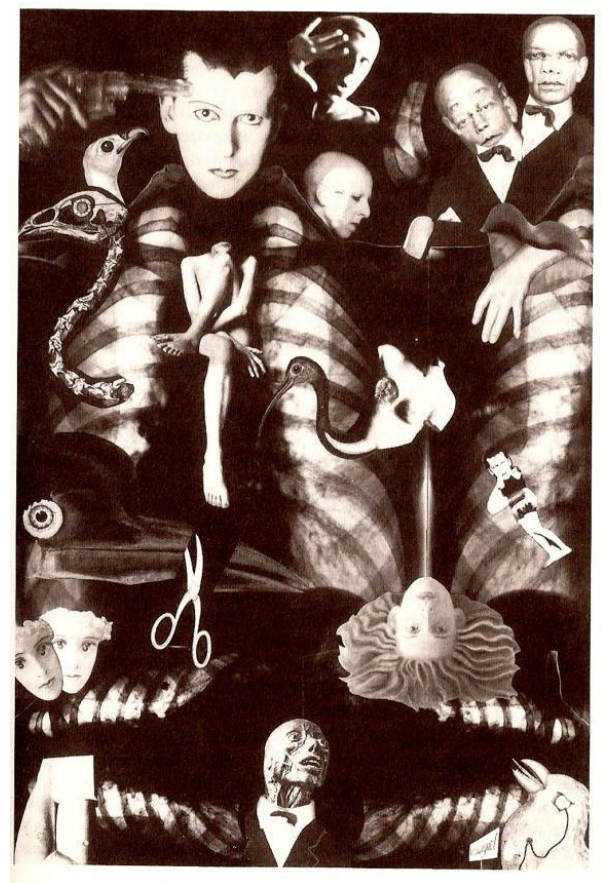

Figura 09. Claude Cahun and Marcel Moore, Untitled plate from Aveux non avenus, 1929-1930, b\&w photograph, Platinum contact print made from 'half plate'-sized glass negative, Size: $55.9 \times 43.2 \mathrm{~cm}$.

\footnotetext{
10 Traduzindo, algo semelhante à 'Confissões não admitidas' ou o título em inglês, 'Disavowals', similar a 'Recusas'.
}

Revista Digital do LAV - Santa Maria - vol. 12, n. 1, p. 54 - 81 - jan./abr. 2019 ISSN 1983 - 7348 http://dx.doi.org/10.5902/1983734832200 
Fonte: @V\&A's collections.

Em 1925, influenciada pelo livro 'Vidas Imaginárias', escrito pelo seu tio, o escritor simbolista Marcel Schwob, e por 'Moralidades Lendárias' de Jules Laforgue, Cahun publica parte de seu manuscrito 'Heroínas'. Trata-se de uma coletânea de contos nos quais realiza sua escrita a partir de uma mirada psicológica, simbólica e, em certos sentidos, também autobiográfica, a exemplo do último conto intitulado 'A Andrógina, heroína das heroínas'; além da desconstrução narrativa histórica sobre mulheres célebres ou desconhecidas da Antiguidade.

Em seu imaginário Cahun escolheu tecer a vida subjetiva de suas personagens sob a temática do narcisismo, da androginia e do onírico misturados à poesia e filosofia, além do uso alternado entre metáforas e escrita culta criando camadas de significação. As heroínas são: 'Eva, a mui crédula'; 'Dalila, mulher entre as mulheres'; 'A sádica Judite'; 'A provocadora (Penélope, a irresoluta)'; 'Helena, a rebelde'; 'Safo, a incompreendida'; 'Maria'; 'Cinderela, a criança humilde e arrogante'; 'Margarida, irmã incestuosa'; 'Salomé, a cética'; 'A Bela'; 'A esposa essencial' ou 'A princesa desconhecida'; 'Sofia, a simbolista'; 'Salmacis, a sufragista'; 'Aquele que não é um herói'; 'A Andrógina, heroína das heroínas'.

Neste último, Claude inicia o conto a partir de uma descrição física de si, como uma espécie de retrato falado, carregado de elementos autobiográficos:

\section{Retrato da Andrógina}

- Seios supérfluos; os dentes pesados e contraditórios; os olhos e cabelos do mais banal dos tons; mãos bastante finas, mas contorcidas e deformadas por um demônio - o demônio da hereditariedade... A cabeça oval do escravo, a testa alta demais... ou baixa demais; um nariz bastante bem-sucedido em seu gênero - ai! um gênero que faz associações desagradáveis de imagens; a boca sensual demais: algo que se pode agradar quando se tem fome, mas assim que se come, causa enjoo; o queixo mal saliente o bastante; e em todo o corpo, músculos apenas esboçados... Vitoriosa!... às vezes vitoriosa dos incômodos mais atrozes, uma destreza tardia corrige uma sombra, um gesto imprudente - e a beleza renasce! Pois diante do espelho, Narciso é tocado pela graça. Ele consente em se reconhecer. E a ilusão que ele cria para si próprio se estende a alguns outros (CAHUN, 2017, p. 95).

Segundo Leperlier, 'exumador' estudioso da obra de Cahun, em 'Heroínas' ela abertamente intenciona ironizar, subverter e atacar a imagem da mulher culturalmente constituída nos contos e mitos, reescrevendo uma nova biografia delas em "outras versões inesperadas, rebeldes, cáusticas e irreverentes" (LEPERLIER, 2017, p. 126). 
A biografia de Claude é tão multifacetada quanto o que podemos investigar através de sua escrita literária e de sua atividade fotográfica. Em 1932, conhece e relaciona-se intelectualmente com o precursor do surrealismo André Breton; eram bastante próximos e nutriam uma verve criativa e "amizade profunda e apaixonada" (CAHUN, 2017).

É desse período a imagem tão simbólica de Cahun dormindo dentro do armário, vestida de 'moçoila sonhadora' com lacinhos no cabelo, blusa de bolinhas e shortinho curto, meia soquete e sapatos brancos (Figura 10). À distância de décadas, podemos hoje ler essa imagem como uma representação da expressão popular 'sair do armário' - que significa assumir a homossexualidade - ou, uma composição estética tipicamente surrealista na qual busca-se agregar o inesperado, o casual, a desorientação, o não convencional, a fuga de padrões, o ilógico, a imaginação na concepção da ideia, do processo e da feitura da obra de arte como elaborada na célebre frase do poeta franco-uruguaio Lautréamont (1846-1870): "Belo como o encontro casual de uma máquina de costura com um guardachuva numa mesa de dissecar cadáveres" (MORAES, 2002, p. 40).

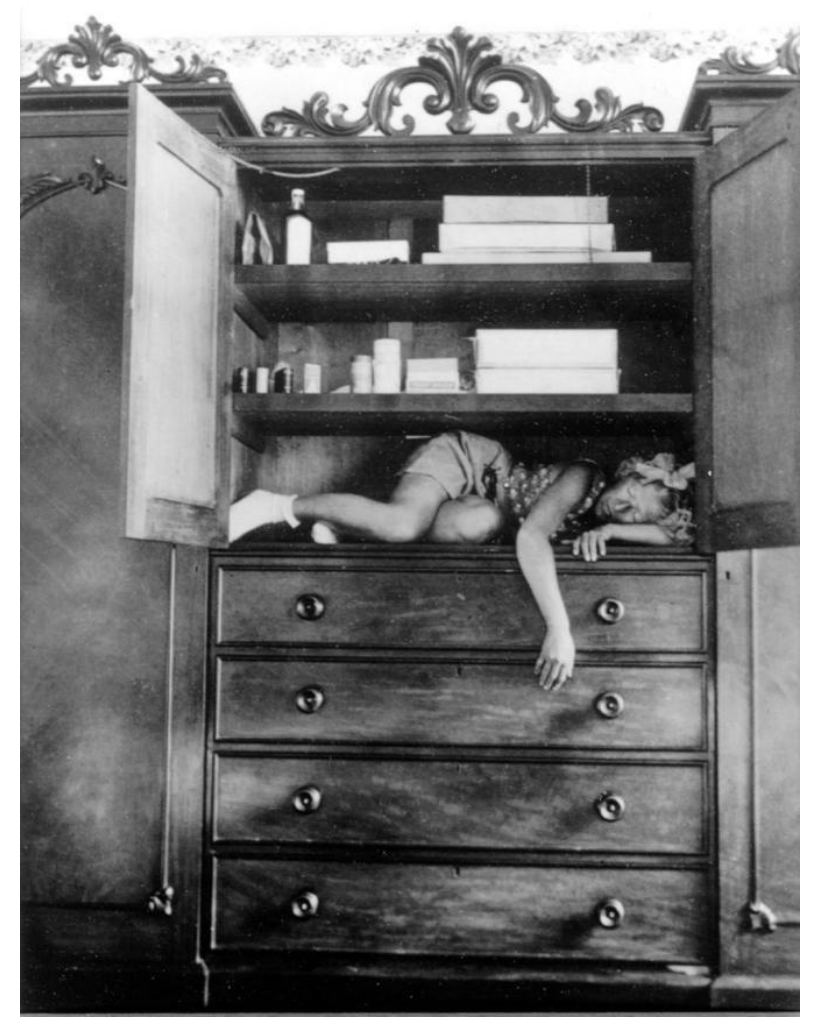

Figura 10. Claude Cahun, Sleeping in my closet , 1932.

Photograph, gelatin silver print on paper.

Fonte: @ theartstack.com. 
Nessa mesma década, Claude associa-se ao movimento surrealista e adere-se à 'Associação de Escritores e Artistas Revolucionários' militando, junto com sua companheira Moore, intensamente nas atividades políticas e sociais afirmando suas posições libertárias. Em 1938, às portas da Segunda Guerra, devido sua origem judaica e sua militância política subversiva, Cahun e Moore deixam Paris e compram uma propriedade na ilha de Jérsei. Continuam mantendo vínculo com os artistas e poetas do grupo surrealista.

Contudo, nesse outro contexto e em atitude de salvaguarda, ambas passam a 'travestirse' e comportar-se socialmente como 'duas senhoras'. As fotografias desse período explicita uma relação entre Claude, retratada por Moore, a nova casa e seu cotidiano. Cahun endossa todo o estereótipo feminino nas roupas, nas poses, na maquiagem e cabelos. Sua nova persona é uma aparente pacata cidadã no alto dos seus 45 anos (Figuras 11 e 12$)$.

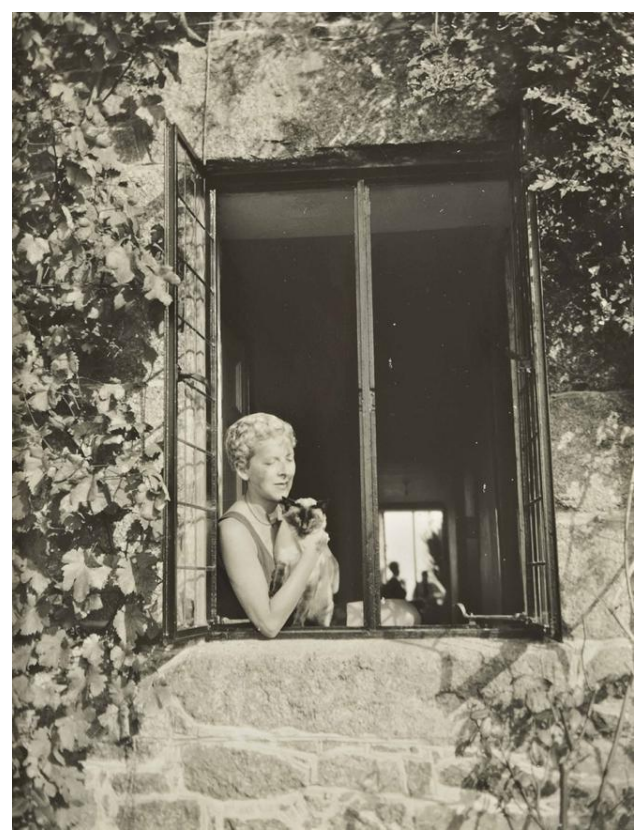

Figura 11. Claude Cahun, SelfPortrait at the window, 1938, photograph, gelatin silver print on paper

Fonte:@museum-joanneum.at

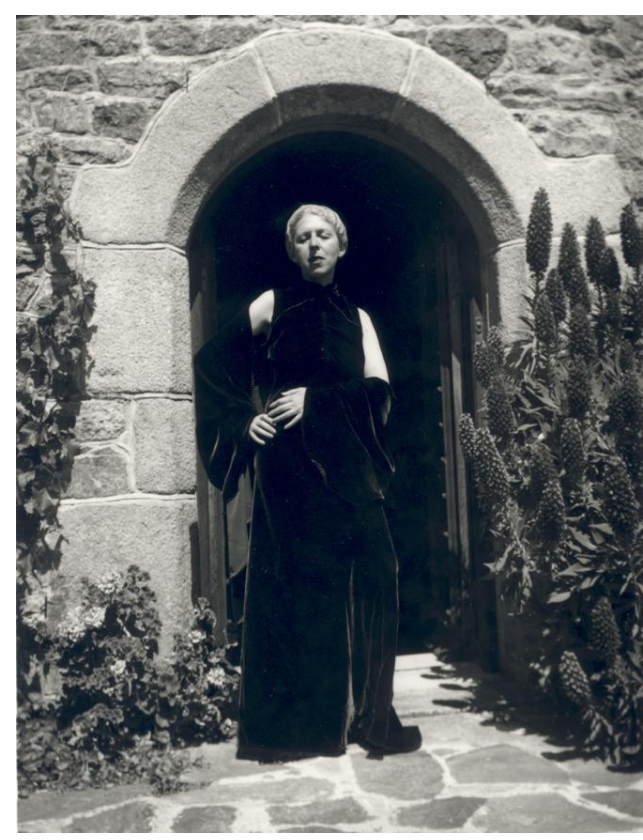

Figura 12. Claude Cahun, Untitled, 1939, photograph, gelatin silver print on paper Fonte: Jersey Heritage Collections

Em 1944, em consequência da incansável militância política em atividades de contrapropaganda da resistência francesa, Claude e Moore são capturadas, presas e condenadas de morte pelos nazistas. Muitos de seus arquivos, principalmente os fotográficos, foram pilhados e destruídos. Ficam detidas até maio de 1945 e, por pouco, escapam da execução. Apesar de sua saúde comprometida após o período do

Revista Digital do LAV - Santa Maria - vol. 12, n. 1, p. 54 - 81 - jan./abr. 2019 ISSN 1983 - 7348 http://dx.doi.org/10.5902/1983734832200 
encarceramento, Cahun realiza novos escritos e notas sobre sua atividade de resistência, inicia a redigir sua autobiografia intitulada Confidences au miroir, além de novos autorretratos. Morre em 1954 de embolia pulmonar.

Em 1992, François Leperlier publica a biografia definitiva de Claude Cahun intitulada L'ecart et la metamorfose (1992) a uma exposição subsequente dos seus enigmáticos retratos. Três anos mais tarde, uma nova exposição de suas fotografias no Musee d'Art Moderne de la Ville de Paris corroborou no crescente interesse de público pelo trabalho do artista.

Sob a tutela de Leperlier o trabalho fotográfico de Cahun começou a ganhar espaço artístico e ser alvo de pesquisadores e aficcionados (entre estes a provocadora artista inglesa Gillian Wearing). Entre 2011 e 2012 uma grande retrospectiva de sua obra passou por três países em dois continentes: começou em Paris no Jeu de Paume (entre 24 maio a 25 setembro de 2011); Barcelona (entre 27 de outubro de 2011 a 29 de janeiro 2012); e no Chicago Art Institute (de 25 fevereiro a 03 junho 2012).

Claude Cahun permaneceu esquecida por meio século e muitos historiadores e críticos de arte buscam algumas possíveis respostas a esse fato. Ocorre que sua fluidez identitária, subjetiva, sexual, artística e política a coloca como algo-alguém desconcertante, incontrolável e, por isso, inclassificável.

Claude engendrou corpos, 'eus', autobiografias ficcionais amalgamadas com situações concretas, mas não tinha interesse pela 'verdade': "Quanto à verdade, será que eu a confessaria para você? Não dou a mínima para isso. Não a procuro - e sim fujo dela. Julgo que seja esse meu verdadeiro dever..." (CAHUN, 2017, p. 114).

\section{Fotografia como escrita de si}

O advento da fotografia, em meados do século XIX, possibilitou um conhecimento inédito do mundo através do congelamento do tempo e da fantasia de imortalidade dos Homens. No século imerso da racionalidade cientificista, antropólogos, arqueólogos, geógrafos, médicos, grupos da esfera judiciária, entre outros, fizeram uso da fotografia como atestado científico de presença e da 'Verdade'.

Não tardou, porém, para que a imagem fotográfica, compreendida até aquele momento como um produto objetivo somente da câmera, passasse pela desconfiança acerca de sua total fidedignidade com o real. Fotografias contendo erros de escalas do mundo natural e 
a suspeita de que o olhar do fotógrafo não era imparcial, levantaram questionamentos sobre as imagens fotográficas a respeito de sua subjetividade e descrédito científico.

Em suas prática inicial, o retrato fotográfico buscou aquilo que já era regra ao retrato pictórico burguês: a preocupação com a nitidez da imagem e o caráter fidedigno na representação do modelo retratado. No início do século XX, porém, a despeito dos detratores da fotografia no final do século anterior, tal produto já era imbuído de valor artístico pois oferecia, justamente, a possibilidade de subverter a realidade tal qual os olhos vêem ou espera-se de uma representação, tornando-se dispositivos para criação artística e posicionamentos críticos das construções sociais.

O autorretrato fotográfico, desde os primórdios, contém o aspecto performativo do olharse olhando. Abarca uma carga erótica do seduzir-se seduzindo. Integra um fetiche do expôr-se, expondo. Envolve um jogo de sedução entre Narciso e seu reflexo, entre a objetiva da câmera e a persona que escolhe-se deixar aparecer.

É inegável que exista um sentido egóico entre apelo sexual e o mistério do não reconhecimento de si ao observar-se refletido na imagem espectral, haja vista a multiplicidade e infinidade de autorretratos ao longo dos séculos na pintura, ao longo das décadas na fotografia e ao longo dos anos no retrato 'selfie':

A auto-representação no retrato contemporâneo se impõe num movimento de superação evidenciado nas modalidades de expressão surgidas ao longo do século passado, como a body art e a performance, e coloca no centro da obra não apenas o autor como motivo, como sugeria a tradição do autorretrato, mas o revela como instrumento e elemento catártico de sua própria expressão. 0 sujeito se vê ante uma imagem que lhe devolve o olhar com outras imagens num processo contínuo de multiplicação de eus, de onde surge uma nova individualidade. O reflexo da imagem em forma de retrato, a visualização de si como outro, a ruptura, a cisão, o corte são marcas desse novo tipo de retrato que guarda muito pouco da tradição do retrato clássico, herdeiro da individualidade aristocrática na pintura, e burguesa, na fotografia (MAZZA; GURAN, 2011, p. 8).

O autorretrato selfie oferece a possibilidade da auto-representação das muitas personas que nos constituem ao proporcionar a agilidade do registro como um diário visual, por ser uma ferramenta efetivamente simples e de acesso relativamente facilitado ao alcance de todos. Já o uso que se faz após o registro, tanto em sua defesa quanto em sua crítica, abarcaria discussões fervorosas em ambos os lados e, definitivamente, seria melhor desenvolvido em outro escopo que não o desse artigo. 
A fotografia na contemporaneidade a partir do contexto, da multiplicidade e variedade de linguagens, do uso de outras ferramentas de edição em sua pós produção, entre outros recursos, é compreendida e validada em seus aspectos de realidade e de ficção.

Claude Cahun nunca buscou 'a Verdade', posicionamento, aliás, extremamente consonante com seu contexto histórico. Em sua luta social e experimentações artísticas buscou promover novas formas de subjetividade através da recusa de apenas um tipo de individualidade imposta. Para ela, mais do que investigar quem era fez-se relevante sua recusa; ampliando o imaginar e construir quem poderia ser.

Uma das formas de sujeição é a imposição social da cristalização da identidade na qual o sujeito só é reconhecido se este se repete, perante aos outros e a si mesmo. Mas sendo o sujeito detentor de múltiplas identidades - civil, social, política, sexual - de qual modo se dá essa cristalização? Com qual das facetas ele se deve repetir? Talvez seja este o ponto de interesse ao pensar na identidade como diferença, havendo uma substituição da problematização da identidade pela luta ao direito à diferença, que por sua vez é uma luta maior que a simples recusa da identidade.

A partir de seus estudos foucaultianos, Margareth Rago referencia a prática do cuidado de si e da estética da existência, elaborada pelos antigos gregos, a partir de uma mirada feminista na qual pretende-se operar uma crítica das identidades estanques, fazer da vida uma obra de arte a partir da prática e da intelectualidade nos novos/outros modos de pensar e fazer a política, relacionar-se com o próprio corpo e com o meio pois,

A critica feminista foi - e tem sido - radical ao buscar a liberação das formas de sujeição impostas às mulheres pelo contrato sexual e pela cultura de massas, e se num primeiro momento o corpo foi negado ou negligenciado como estratégia dessa recusa das normatizações burguesa, desde os anos 1980 percebem-se uma mutação nessas atitudes e uma busca de ressignificação do feminino (RAGO, 2013, p. 25).

Nesse sentido, a partir de seus retratos e autorretratos, Claude constituiu tanto um espaço de um 'eu' expandido quanto a relação com o Outro, encontrou voz na fuga dos discursos e pressupostos ontologizantes, humanistas e essencialistas a partir de sua afirmação constitutiva no processo e no limiar entre um alguém e outro, tecendo a sua própria experiência sem render-se ao aprisionamento ideológico e identitário. Cahun tornou-se sujeito diaspórico e sincrético. 
Entremeados nas discursividades filosóficas-políticas, a arte é afirmada como parte fundamental na tomada da existência e resistência ao poder e ao controle que nos foram impostos por todos os enunciados que nos constituem.

Se não em todos, a maioria dos autores referência deste artigo explicitam a profunda relação entre arte ou criação - de modo generalizado, porém no sentido do inédito - e micropolítica, como possibilidade da reinvenção de si e do coletivo na afirmação de resistência e criação de potencialidades.

\section{Considerações finais}

A noção de indivíduo, na condição de modelo e referência, é instituída na modernidade e suas experiências coletivas e particulares tornam-se objeto de relevância e reflexão nas variadas esferas do conhecimento. Do marxismo à psicanálise, a interpretação da subjetividade e as inúmeras indagações filosóficas sobre a presença do sujeito no mundo, obviamente abordadas na arte, avançam períodos e estilos se reafirmando em todo século XX. A busca da 'Verdade' está sob suspeita.

As interrogações sobre os limites do indivíduo investem com interesse quase obsessivo o privado e o íntimo, potencializando a ideia de identidade não como algo compacto e homogêneo, mas de um 'eu' constituído por tantos 'nós', multiplicando possibilidades de auto-representações e modos de devir.

Claude Cahun continua inclassificável. Está, aparentemente, em algum lugar entre lugares: denominações, linguagens, gêneros, realidade e autoficção, entre o inédito e o mítico. Suas experiências radicais na arte, literatura e na política fizeram-na, simultaneamente, tanto vanguardista quanto outsider. Propôs a fluidez entre os papéis identitários, pois não Ihe interessava repetir-se para os outros, muito menos para si própria. Rompeu, no início do século $X X$, as categorias binárias e dualismos impostos pela normativa social.

Embora por tanto tempo esquecida, foi uma figura chave no movimento surrealista e, quando redescoberta no final dos anos 1970, tornou-se referência à artistas contemporâneas como, por exemplo, a norte-americana Cindy Sherman e a inglesa Gillian Wearing, ambas com temáticas que problematizam questões de identidade e corpo; além de historiadores e críticos de arte que investigam a partir de perspectivas teóricas pósmodernas, feministas e queer.

Sob o controle dos corpos e da sexualidade a partir dos retrocessos de tempos recentes, um trabalho como de Claude Cahun, realizado há quase um século, continua sendo tanto

Revista Digital do LAV - Santa Maria - vol. 12, n. 1, p. 54 - 81 - jan./abr. 2019 ISSN 1983 - 7348 http://dx.doi.org/10.5902/1983734832200 
inédito quanto atualíssimo. As construções sociais que intentam controlar limites entre os gêneros, os modos de viver a sexualidade e os desejos continuam infelizes apesar da evidente mudança dos tempos.

O que ela buscou em sua arte-vida era a experimentação de sua identidade e não uma definição desta. Cahun buscava e propunha a reinvenção, a personificação, um mascararse para logo em seguida, trocar as facetas. A sua 'verdade' é constantemente tecida com a ficção, pois "Sob esta máscara, outra máscara; nunca terminarei de remover todas essas caras", escreveu ela.

\section{Referências}

BRAUNE, F. O surrealismo e a estética fotográfica. Rio de Janeiro: 7letras, 2000.

CAHUN, C. Heroínas. Rio de Janeiro, RJ: Editora A Bolha, 2017.

FOUCAULT, M. O Sujeito e o poder. In: DREYFUS, H.; RABINOW, P. Michel Foucault. Uma trajetória filosófica: para além do estruturalismo e da hermenêutica. Rio de Janeiro: Forense Universitária,1995. p. 231-249.

FOUCAULT, M. "A escrita de si". In: MOTTA, M.B.; MONTEIRO, I.; BARBOSA, A.D. (Org.) Ética, sexualidade e política. Coleção Ditos e Escritos, v.V. Rio de Janeiro: Forense Universitária, 2004. p. 144-62.

FRAYZE-PEREIRA, J. A. Arte, Dor: Inquietudes entre estética e psicanálise. Cotia, SP: Ateliê Editorial, 2005.

HAWKINS, A. Meet Rrose Sélavy: Marcel Duchamp's Female Alter Ego, December 01, 2015. Disponível em: https://www.anothermag.com/art-photography/8084/meet-rroseselavy-marcel-duchamp-s-female-alter-ego. Acesso em: 17 abr. 2018.

JUNG, C. G. O homem e seus símbolos. Rio de Janeiro: Nova Fronteira, 2008.

LEPERLIER, F. Fábulas intempestivas. In: Heroínas de Claude Cahum. Rio de Janeiro, RJ: Editora A Bolha, 2017.

LEPERLIER, F. L'ecart et la metamorfose: essai. Paris: Jean Michel Place, 1992. 
MAZZA, J.; GURAN, M. Eu me desdobro em muitos: a autorrepresentação na fotografia contemporânea. Catálogo da mostra expositiva, CCBB, Rio de Janeiro, 2011.

MORAES, E. R. O corpo impossível: a decomposição da figura uma de Lautréamont a Bataille. São Paulo: Iluminuras, FAPESP, 2002.

NIETZSCHE, F. W. A gaia ciência. São Paulo: Companhia das Letras, 2012.

PERROT, M. Minha história das mulheres. São Paulo: Contexto, 2017.

PRADO FILHO, K. A política das identidadades como pastorado contemporâneo, In: Foucault e o Cristianismo. Belo Horizonte: Autêntica Editora, 2010.

RAGO, M. A aventura de contar-se: feminismos, escrita de si e invenções da subjetividade. Campinas, SP: Editora da Unicamp, 2013.

\begin{abstract}
i Artista visual, fotógrafa e pesquisadora. Doutoranda em Artes Visuais pela Universidade do Estado de Santa Catarina (UDESC), na linha de pesquisa Processos Artísticos Contemporâneos. Mestra em Psicologia Social pela Universidade Federal de Santa Catarina (UFSC). Licenciada em Educação Artística com habilitação em Artes Plásticas, pela Fundação Armando Alvares Penteado (FAAP | SP). Membro do grupo de pesquisa Articulações Poéticas (CNPq/UDESC) e do Núcleo de Estudos em Fotografia e Arte (NEFA). Bolsista PROMOP em atividade. Tem experiência profissional no ensino fundamental e médio, na área de Artes Visuais e Fotografia. Como fotógrafa vem participando e recebendo premiações em exposições e festivais de fotografia em São Paulo, Santa Catarina, Rio de Janeiro e Minas Gerais. Atualmente, desenvolve pesquisas abrangendo corpo e autorepresentação como estratégia de problematização do feminino através da fotografia autoral. Portfólio visual disponível em: http://www.anasabia.com
\end{abstract}

Como citar esse artigo:

SABIÁ, Ana Paula. A fotografia performática de Claude Cahun. Revista Digital do LAV, Santa Maria: UFSM, v. 12, n. 1, p. 55-81, jan./abr. 2019. 